\title{
Job separations in the UK
}

\section{Katherine Kent \\ Office for National Statistics}

\section{SUMMARY}

This article provides the latest estimates, for the period 1996 to 2007, of total job separations, defined as the end of the employment relationship between employer and employee. This can happen for many reasons. For example, the employee could choose to leave to have a child or for a better-paid job; conversely, they could be forced to leave at the end of a temporary contract, or be made redundant by their employer.

The article is the latest in a series produced by the Office for National Statistics. Earlier Labour Market Trends articles by Weir (2003) and Heap (2005) analysed job separations and the links with the economic climate. This article updates some of the key tables on job separations and uses longitudinal analysis to give more details on previous jobs.
$\Lambda$ nalysing job separations can help assess the current economic climate, as they are indicators of employment turnover. However, a higher level of job separations can indicate both growth and decline in the economy. High labour demand can create jobs, so more people leave existing jobs for better ones, whereas when labour demand is low, the employer may not readvertise once a job is left, or has to make employees redundant.

\section{Labour Force Survey}

The Labour Force Survey (LFS) is a

quarterly household survey covering 53,000 households in the UK. The LFS is one of the principal sources for key information on the state of the labour market. It provides information on an employee's reason for leaving their last job, as well as more detailed characteristics about the respondent.
The LFS structure enables the linking of individuals over two or five quarters. The longitudinal data sets cover the workingage population. This data set will be used to analyse previous job characteristics not covered by the quarterly LFS.

\section{Job separations}

The level of job separations is defined as the number of people who left their main paid job in the previous three months. The main reason for leaving their job is captured in the LFS question, 'What was the reason why you left your last job?' (see Box 1). There are nine possible reasons for leaving, of which three describe involuntary separations and six voluntary separations. An involuntary job separation is where the employer decides to terminate the employment. Voluntary separations are where the employee decides to leave their job. It

\section{Box 1}

Full LFS question on reason left last job, and classification of involuntary and voluntary separations

Could you tell me the reason why you left your last job?

1 Dismissed

2 You were made redundant/took voluntary redundancy

3 It was a temporary job which came to an end Involuntary

4 You resigned

5 You gave up for health reasons

6 You took early retirement

7 You retired (at or above state pension age)

8 You gave up work for family or personal reasons

9 You left for some other reason 
should be noted that those people who have experienced a job separation in the previous three months may have had more than one job separation.

The number of job separations fluctuates throughout the year. They are lowest in the first quarter (January to March) and highest in the final quarter (October to December). Combining data for four calendar quarters and presenting a yearly average smoothes these fluctuations. The question on job separations was introduced in the LFS in quarter two of 1995 and so data are presented from 1996 (the first full year's worth of data) for all people aged 16 and over. In 1996, there were 1.15 million job separations, reaching a high of 1.30 million in 1998 before falling to 1.04 million in 2007. One-quarter of job separations are involuntary and three-quarters are voluntary.

\section{Job separation rates}

Comparing the number of job separations over time is influenced by the number of people who are in employment. Using a job separation rate factors this in. It is calculated as the number of working-age people separated from a paid job in the three months before interview, divided by the number of people who said they were in employment for more than three months, plus those separated from a paid job. The population is restricted to working-age, which is men aged 16 to 64 and women aged 16 to 59 . For further information on calculating job separation rates, see the Technical Note.

Figure 1 shows job separation rates for 1996 to 2007. Between 1996 and 2007, the total job separation rate fell from 4.4 per cent to 3.6 per cent. The involuntary separation rate fell from 1.6 per cent in 1996 to 1.0 per cent in 2007 . The voluntary separation rate in 1996 was 2.9 per cent, rising to 3.3 per cent in 1998 before falling back to 2.5 per cent in 2007 , with the biggest drop between 2004 and 2005.

\section{Job separation rates by sex}

Figure 2 shows the involuntary and voluntary separation rates of men and women for the period 1996 to 2007.

Overall, women have higher total separation rates than men. Women have the lowest involuntary separation rates and the

\section{Figure 1}

\section{Total, involuntary and voluntary separation rates, 1996 to $2007^{1}$}

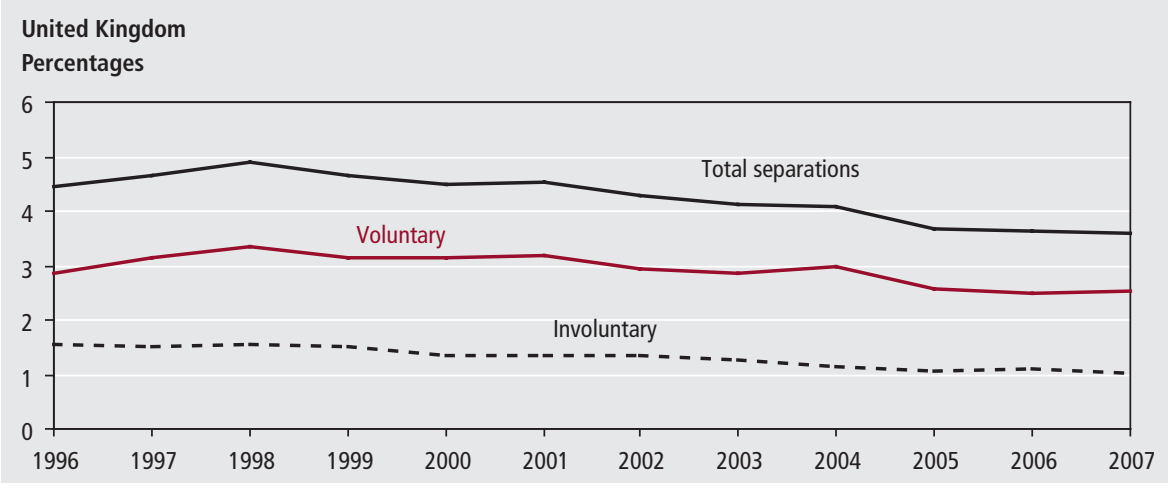

Note:

Source: Labour Force Survey

1 Four-quarter average of Q1, Q2, Q3 and Q4 of each year.

\section{Figure 2}

\section{Involuntary and voluntary separation rates: by sex, 1996 to $2007^{1}$}

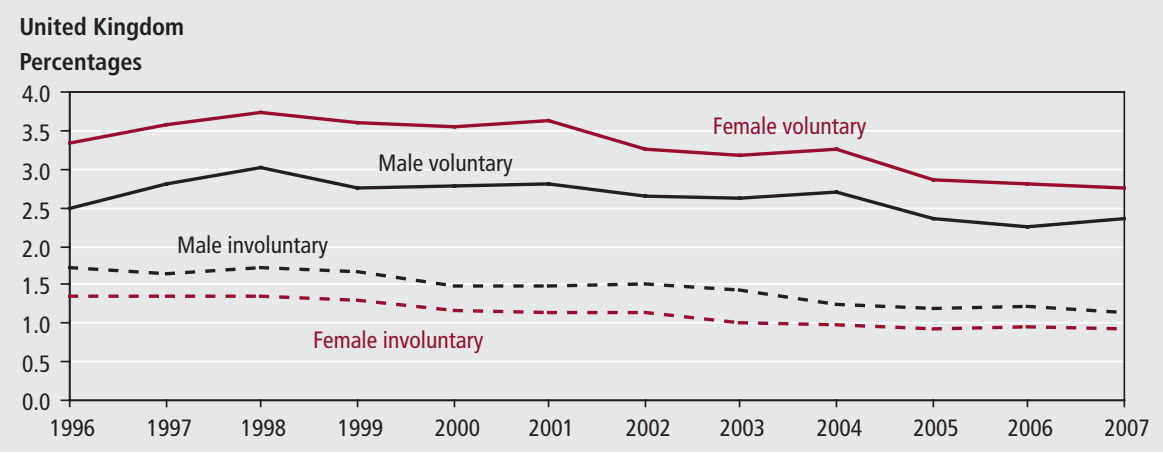

Note:

Source: Labour Force Survey

1 Four-quarter average of Q1, Q2, Q3 and Q4 of each year.

highest voluntary separation rates. In 2007, these rates were 0.9 per cent and 2.8 per cent, respectively; for men, the respective rates were 1.1 per cent and 2.4 per cent. The voluntary separation rate was lowest in 2006 for men, at 2.3 per cent. The difference in voluntary separation among men and women has narrowed since 1995.

\section{Job separation rates by age}

Table 1 shows the job separation rates by four age bands in 1996 and 2007. In both years, 16 to 24 year olds have the highest job separation rates, representing the fact that they move jobs more frequently. They are in the early stages of their careers and possibly looking to progress, or could be students with casual jobs. In 1996, their rate was 10.2 per cent, falling to 8.5 per cent by 2007 . Compared with 4.0 per cent of those aged 25 to $34,2.5$ per cent aged 35 to 49 and also 2.5 per cent aged 50 to retirement age left their jobs in 2007 .

\section{Reason for leaving}

Table 2 shows the reasons for leaving a job, for people of working age who separated from their job in the previous three months, with early retirement and retirement combined into one group. For around one in five people, 'left for some other reason' is given as the reason for leaving their last job. In 2007, the most common reason was resignation, accounting for 38.4 per cent. A temporary job ending accounted for 13.9 per cent of job separations and 'made redundant/voluntary redundancy' accounted for a further 12.1 per cent. Since 1996, the proportion leaving because of resignation has increased, with falls among most of the other groups.

It should be noted that there could be reporting errors with the reason for the job separation: for example, dismissals may be under-reported. Also, in proxy responses (where someone responds on behalf of someone else), the real reason for leaving may not be accurate.

\section{Economic activity status following a job separation}

Table 3 shows the current economic activity status for working-age people who separated from a job in the previous three months. Re-employment rates show the proportion of people separated from their main job in the three months before their interview who were in employment again at their next interview. The re-employment rate for all separations was 57.7 per cent in 2007, but this varies among the reasons for leaving. Approximately three-quarters 
Table 1

\section{Total job separations rates: by age}

United Kingdom

\begin{tabular}{lrrrr}
\hline & $\mathbf{1 6 - 2 4}$ & $\mathbf{2 5 - 3 4}$ & $\mathbf{3 5 - 4 9}$ & $\mathbf{5 0 - 5 9 / 6 4}$ \\
\hline $1996^{1}$ & 10.2 & 4.7 & 2.8 & 2.5 \\
$2007^{1}$ & 8.5 & 4.0 & 2.5 & 2.5 \\
\hline
\end{tabular}

Note:

Source: Labour Force Survey

1 Four-quarter average of Q1, Q2, Q3 and Q4 of each year.

Table 2

Job separations, working-age people: ${ }^{1}$ by reason for leaving ${ }^{2}$

United Kingdom

Percentages

\begin{tabular}{lrr}
\hline & $1996^{3}$ & $2007^{3}$ \\
\hline Dismissed & 3.2 & 2.9 \\
Made redundant/voluntary redundancy & 14.2 & 12.1 \\
Temporary job ended & 17.8 & 13.9 \\
Involuntary & 35.2 & 28.9 \\
Resigned & 25.3 & 38.4 \\
Gave up work for health reasons & 4.5 & 3.2 \\
Took early retirement/retired & 2.1 & 2.2 \\
Gave up work for family, personal reason & 10.1 & 7.6 \\
Left for some other reason & 22.9 & 19.6 \\
Voluntary & 64.8 & 71.1 \\
All separations & 100.0 & 100.0 \\
\hline
\end{tabular}

\section{Notes:}

Source: Labour Force Survey

1 Working-age men aged 16-64 and women aged 16-59.

2 Excludes those who did not state a reason.

3 Four-quarter average of Q1, Q2, Q3 and Q4 of each year.

Table 3

\section{Economic status of working-age ${ }^{1}$ people who have separated ${ }^{2}$ from a} job: by reason for leaving, $2007^{3}$

United Kingdom

Percentages

\begin{tabular}{|c|c|c|c|}
\hline & Employed & Unemployed & Inactive \\
\hline Dismissed & 31.8 & 51.4 & 16.8 \\
\hline Made redundant/voluntary redundancy & 41.6 & 40.8 & 17.6 \\
\hline Temporary job ended & 48.7 & 31.1 & 20.1 \\
\hline Involuntary & 44.0 & 37.2 & 18.7 \\
\hline Resigned & 73.7 & 14.9 & 11.4 \\
\hline Gave up work for health reasons & 17.4 & 18.2 & 64.4 \\
\hline Took early retirement/retired & 9.2 & 6.7 & 84.1 \\
\hline Gave up work for family, personal reason & 6.6 & 10.3 & 83.0 \\
\hline Left for some other reason & 35.6 & 19.8 & 44.6 \\
\hline Voluntary & 63.4 & 15.1 & 21.5 \\
\hline All separations ${ }^{4}$ & 57.7 & 21.5 & 20.8 \\
\hline
\end{tabular}

\section{Notes:}

Source: Labour Force Survey

1 Working-age men aged 16-64 and women aged 16-59.

2 Separated from a job in the three months before interview.

3 Four-quarter average of Q1, Q2, Q3 and Q4 2007.

4 Includes those who did not state a reason for leaving.

of those resigning were in employment, these people more likely to have already had jobs lined up before resigning. Among people who had been dismissed, 51.4 per cent were unemployed; of those made redundant/voluntary redundancy, 40.8 per cent were unemployed and 41.6 per cent were employed.

\section{Longitudinal analysis}

Apart from redundancies, there is no information on the previous job if a respondent is in a new job at interview. Using longitudinal analysis examines data sets for 2007 to overcome seasonality and increase the sample size.

\section{Working patterns and job type}

Table 4 shows that the total job separation rate in 2007 among full-time jobs was 3.2 per cent, compared with 4.9 for those whose main job was part-time. Non-permanent jobs have a total job separation rate of 13.5 per cent compared with 3.4 for permanent jobs.

Job tenure and occupation The job separation rates are higher among people who have held their job for the least amount of time. The separation rate is 12.0 per cent among people who had been in the job for less than three months (5.3 per cent for involuntary separations and 7.4 per cent for voluntary separations) compared with 1.7 per cent ( 0.5 per cent involuntary and 1.2 per cent voluntary separations) for those in the job for more than five years. This indicates that the first three months are critical in determining the suitability of both the job and employee.

The private sector has higher job separation rates than the public sector (4.1 per cent compared with 2.1 per cent). The LFS is not the most reliable source for measuring public sector employment, as sometimes people are unsure to which sector they belong.

By occupation, 'sales and customer service occupations' have the highest job separation rate in 2007, at 6.6 per cent, with the lowest separation rate being 2.3 per cent in professional occupations. This fits in with the perception that sales occupations are high pressure and that those who invest time in becoming professionals are less likely to change their jobs; likewise, employers who invest in their staff to become a professional are less likely to terminate contracts once they reach their professional status.

\section{Conclusion}

In 2007, there were approximately 1 million job separations and the job separation rate was 3.6 per cent. There are twice as many voluntary separations as involuntary separations. Men have more involuntary job separations than women; one-third of job separations among men are involuntary. Women have more voluntary separations; three-quarters of job separations among women are voluntary. The highest job separation rates are among 16 to 24 year olds. The re-employment rate for voluntary separations is 63.4 per cent, driven by a high re-employment rate among those 
Table 4

Job separation rates: by previous job characteristics, ${ }^{1,2,3} 2007^{4}$

United Kingdom

\begin{tabular}{|c|c|c|c|}
\hline & $\begin{array}{l}\text { Involuntary } \\
\text { separations }\end{array}$ & $\begin{array}{r}\text { Voluntary } \\
\text { separations }\end{array}$ & $\begin{array}{r}\text { Total job } \\
\text { separations }\end{array}$ \\
\hline \multicolumn{4}{|l|}{ Working pattern } \\
\hline Full-time & 1.0 & 2.3 & 3.2 \\
\hline Part-time & 1.2 & 3.8 & 4.9 \\
\hline \multicolumn{4}{|l|}{ Job type ${ }^{5}$} \\
\hline Permanent & 0.8 & 2.7 & 3.4 \\
\hline Non-permanent & 8.0 & 6.4 & 13.5 \\
\hline \multicolumn{4}{|l|}{ Job tenure } \\
\hline Less than three months & 5.3 & 7.4 & 12.0 \\
\hline Three months to one year & 2.4 & 5.2 & 7.4 \\
\hline One to two years & 1.0 & 4.0 & 5.0 \\
\hline Two to five years & 0.7 & 2.5 & 3.1 \\
\hline Five years or more & 0.5 & 1.2 & 1.7 \\
\hline \multicolumn{4}{|l|}{ Public or private sector ${ }^{5}$} \\
\hline Public & 0.6 & 1.5 & 2.1 \\
\hline Private & 1.2 & 3.0 & 4.1 \\
\hline \multicolumn{4}{|l|}{ Occupation } \\
\hline Managers and senior officials & 0.7 & 2.0 & 2.7 \\
\hline Professional occupations & 0.8 & 1.6 & 2.3 \\
\hline Associate professional and technical & 0.7 & 1.9 & 2.6 \\
\hline Administrative and secretarial & 0.9 & 2.6 & 3.9 \\
\hline Skilled trades occupations & 1.1 & 2.1 & 3.2 \\
\hline Personal service occupations & 0.6 & 2.9 & 3.4 \\
\hline Sales and customer service occupations & 1.2 & 5.1 & 6.6 \\
\hline Process, plant and machine operatives & 1.2 & 2.4 & 3.5 \\
\hline Elementary occupations & 1.7 & 4.6 & 6.2 \\
\hline
\end{tabular}

\section{Notes:}

Source: Longitudinal Labour Force Survey

1 All characteristics are based on self-classification.

2 Base for percentages excludes unknowns.

3 Assumes that job at wave one was the last job: this may or may not be the case.

4 Average of four longitudinal data sets Q4 2006 to Q1 2007, Q1 to Q2 2007, Q2 to Q3 2007 and Q3

to Q4 2007.

5 Applies to employees only. who resigned, but is only 44.0 per cent for involuntary separations.

Additional analysis using the longitudinal data sets gives more information on the job separated from. Among these findings, the job separation rate is 4.9 per cent for part-time jobs, and 12.0 per cent for people who have been in the job for less than three months.

Job separations can also indicate a mismatch of skills, for example, employees outperforming their role; this is supported by a high proportion of resignations. Unfortunately, the LFS does not find out the details of why these jobs were left and cannot find out what happens to the job once someone has left.

\section{CONTACT}

(凶)elmr@ons.gsi.gov.uk

\section{REFERENCES}

Heap D (2005) 'Job Separations in the UK', Labour Market Trends 113(6), pp 231-8.

Weir G (2003) 'Job Separations', Labour Market Trends 111(3), pp 121-32.

\section{TECHNICAL NOTE}

Job separation rate construction method

Job separations can be expressed as quarterly rates. These are derived from a count of the number of people who have left a paid job, not the total number of job separations, as a small number of people may have left more than one paid job in the three months before interview. However, because respondents are not asked what their economic activity status was three months ago, the denominator for the rate has to be constructed by adding the number of people who have been employed for more than three months to the number of people who separated from a job in the three months prior to interview. Quarterly job separation rates can be expressed as follows:

$\Sigma$ working-age people to separate from paid job (per quarter)

$\Sigma$ working-age people to separate from paid job (per quarter) + employed for more than three months

In Figures 1 and 2 and Tables 1 and 2, job separation rates are expressed as four-quarter averages. In this case, the separation rate is constructed as:

$\Sigma$ working-age people to separate from paid job (from all four quarters) + employed for more than three months 